\title{
PERANCANGAN DAN PENERAPAN ALGORITMA NAKULA SADEWA UNTUK MENGATASI DUPLIKASI PEMILIHAN DI TEMPAT PEMUNGUTAN SUARA
}

\author{
Yogi Priyo Prayogo, Hero Wintolo, Yuliani Indrianingsih \\ Teknik Informatika STTA Yogyakarta \\ informatika@stta.ac.id
}

\begin{abstract}
The security of election's data in a manual election process is susceptible to some fraud activity, one of them is voter's identity theft activity which will be used to vote more than one time. The regulation which allow the voter to vote on another town has became a hole that can be used the perpetrator to vote using stolen identity as no one knows him and his true identity. This fraud activity will have direct impact to the result of election. This fraud can be contained by using Nakula Sadewa Algorithm which will analyze and compare the voter's home voting place to the voting place that the voter's use to do the voting activity. The voter's can still vote on another town, but heavily encouraged to vote on his hometown.
\end{abstract}

Keywords : Nakula Sadewa Algorithm, Election, Vote

\section{PENDAHULUAN}

Dalam sebuah masyarakat yang menganut paham demokrasi, seorang pemimpin harus dipilih secara terbuka oleh anggota masyarakatnya. Yang berhak menjadi pemimpin adalah yang mempunyai suara dukungan paling banyak dari anggota masyarakat. Proses pemilihan pemimpin masyarakat selama ini dilakukan dengan cara manual mulai dari proses pemilihan sampai ke proses perhitungan suara. Cara ini membutuhkan sumber daya yang cukup banyak serta memiliki banyak celah kecurangan. Dengan menggunakan cara berbasis teknologi informasi, proses pemilihan pemimpin masyarakat akan menjadi lebih hemat sumber daya dan menutup beberapa celah kecurangan yang ada. Tapi dengan cara ini pun masih ada beberapa celah kecurangan salah satunya adalah kecurangan memilih lebih dari satu kali dengan cara menggunakan identitas curian milik pemilih lain. Cara ini mudah dilakukan karena seorang pemilih diijinkan untuk memilih di Tempat Pemungutan Suara (TPS) di luar tempat tinggalnya. Dengan begitu orang bisa berpura-pura sebagai pemilih dari TPS daerah lain dan saksi saksi tidak akan curiga meskipun mereka tidak mengenalnya dan suaranya akan dihitung sebagai suara yang sah mengingat tidak ada identitas pengenal pada surat suara. Untuk mengatasi ancaman keamanan yang terjadi dari kecurangan ini, bisa dengan menggunakan Algoritma Nakula Sadewa. Algoritma Nakula Sadewa ini adalah suatu algoritma penyaringan lanjut yang akan membantu mengenali antara input data pemilihan sah yang memang berasal dari pemilih yang sah dan membuat input data pemilihan palsu yang berasal dari kecurangan. 


\section{LANDASAN TEORI}

\section{Pemilihan Pemimpin Masyarakat Manual}

Proses pemberian suara pada pemilihan pemimpin masyarakat konvensioal bisa kita amati pada Pemilu tahun 2009. Proses pertama adalah pemilih datang dan mendaftar ke TPS terdekat. Caranya adalah dengan menunjukkan surat undangan pemilu yang dimiliki. Bila pemilih tidak bisa menunjukkan surat undangan maka pemilih akan ditolak dan tidak bisa mengikuti proses pemilu. Bila pemilih bisa menunjukkan surat undangan pemilunya maka pemilih akan didaftarkan dan dipersilahkan menunggu antrian. Jika sudah gilirannya maka pemilih akan menerima surat suara dan memberikan suaranya di dalam bilik suara. Setelah itu surat suara dimasukkan ke kotak suara dan langkah terakhir adalah jari pemilih akan dicelup ke dalam tinta untuk menunjukkan bahwa sang pemilih telah melakukan proses pemilihan. Dari proses di atas dapat dilihat bahwa tidak ada proses verifikasi untuk membuktikan bahwa surat suara yang dibawa oleh pemilih adalah benar-benar miliknya. Hal ini sangat rawan khususnya pada kasus pemilih yang berasal dari TPS lain. Para saksi dan petugas tidak akan curiga karena mereka juga tidak mengenal pemilih yang berasal dari TPS lain. Pada surat panggilan pemilu juga tidak dicantumkan foto atau bukti pengenal lain yang bisa membantu untuk mengenali pemilik sah surat suara tersebut. Hal ini bisa menyebabkan terjadinya penggelembungan jumlah suara karena tidak ada mekanisme untuk mengecek sah atau tidaknya hak suara seorang pemilih.

Tentunya bisa dimanfaatkan untuk kepentingan pihak-pihak tertentu yang berkepentingan dengan hasil pemilu.

\section{Pemilihan Pemimpin Masyarakat berbasis Teknologi Informasi}

Pemilihan pemimpin masyarakat berbasis teknologi informasi adalah proses pemilihan pemimpin masyarakat yang memanfaatkan kemajuan teknologi informasi dalam pelaksanaanya. Penggunaan sistem yang terkomputerisasi dan jaringan komputer membawa beberapa manfaat diantaranya :

1. Penghematan biaya

Karena tidak lagi menggunakan kertas suara maka biaya pembelian \& pencetakan surat suara dan biaya tenaga pelipatan surat suara bisa dihilangkan.

2. Penghematan waktu

Dengan tidak menggunakan lagi kertas suara maka waktu yang digunakan untuk proses menyiapkan surat suara mulai dari persiapan sampai distribusi surat suara bisa dimanfaatkan untuk kegiatan lain. Proses penghitungan surat suara pun tidak membutuhkan banyak waktu sebagaimana proses pemilihan pemimpin masyarakat manual.

Untuk alur kerjanya sendiri, mirip dengan alur kerja pemilihan pemimpin masyarakat secara manual, hanya saja hampir semua proses input $\mathcal{E}$ output data dilakukan secara terkomputerisasi untuk menekan terjadinya human error.

\section{PERANCANGAN ALGORITMA}

Algoritma Nakula Sadewa adalah sebuah algoritma penyaringan lanjut yang bertujuan untuk meningkatkan keamanan data pemilihan pada sistem pemilihan pemimpin masyarakat dari ancaman menggunakan hak pilih lebih dari satu kali dengan menggunakan identitas 
curian milik pemilih lain. Algoritma ini merupakan sebuah pengembangan dari algoritma yang digunakan pada Pilkadus Jembrana Bali yang dikembangkan oleh Badan Pengkajian dan Penerapan Teknologi (BPPTK), jadi algoritma ini juga mempunyai fitur lain seperti pengecekan apakah pemilih telah terdaftar pada Daftar Pemilih Tetap (DPT). Bila dibandingkan dengan data pemilih dari sistem pemilu manual dan sistem e-voting Pilkadus Jembrana, algoritma ini hanya membutuhkan satu data tambahan bagi masing-masing individu pemilih yang bisa digunakan dalam proses identifikasi. Data tambahan ini akan digunakan sebagai tambahan kunci pembanding yang bersifat personal, contohnya sidik jari, retina mata, kartu identitas pintar, password dan lain sebagainya. Dalam tugas akhir ini, data tambahan yang digunakan adalah password. Password dipilih karena selain low cost, sudah teruji keefektifannya di lapangan, dan juga bersifat rahasia. Algoritma Nakula Sadewa memakai 3 kunci pembanding dalam proses penyaringannya yang terdiri dari :

1. Nomor Identitas (ID) Pemilih Terdaftar

Nomor identitas pemilih terdaftar adalah nomor unik yang digunakan untuk mendaftarkan pemilih pada Daftar Pemilih Tetap (DPT). Nomor ini akan di-generate oleh sistem berdasarkan nomor kartu identitas calon pemilih dikombinasikan dengan beberapa karakter tertentu. Nomor kartu identitas yang digunakan adalah dari kartu identitas yang diakui oleh otoritas lembaga penyelenggara kegiatan pemilihan ketua masyarakat, misalnya nomor Kartu Tanda Penduduk (KTP) atau nomor Surat Ijin Mengemudi (SIM).

2. Password Pemilih

Password ini akan di-generate secara random dan diberikan kepada masing masing pemilih oleh sistem pada saat proses pendaftaran pemilih untuk dimasukkan ke dalam DPT.

3. Nama Tempat Pemungutan Suara (TPS) Asal

Dalam surat undangan pemilihan yang diterima oleh pemilih akan tercantum pula keterangan nama TPS asal, yaitu nama TPS yang berlokasi di daerah asal pemilih tersebut sesuai yang tercantum pada kartu identitas.

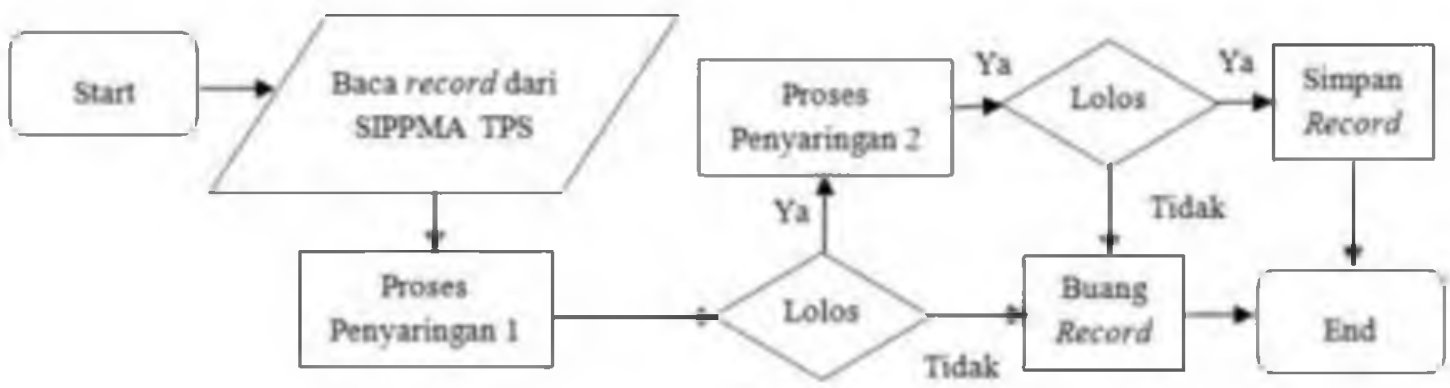

Gambar 1. Diagram alir proses keseluruhan Algoritma Nakula Sadewa 


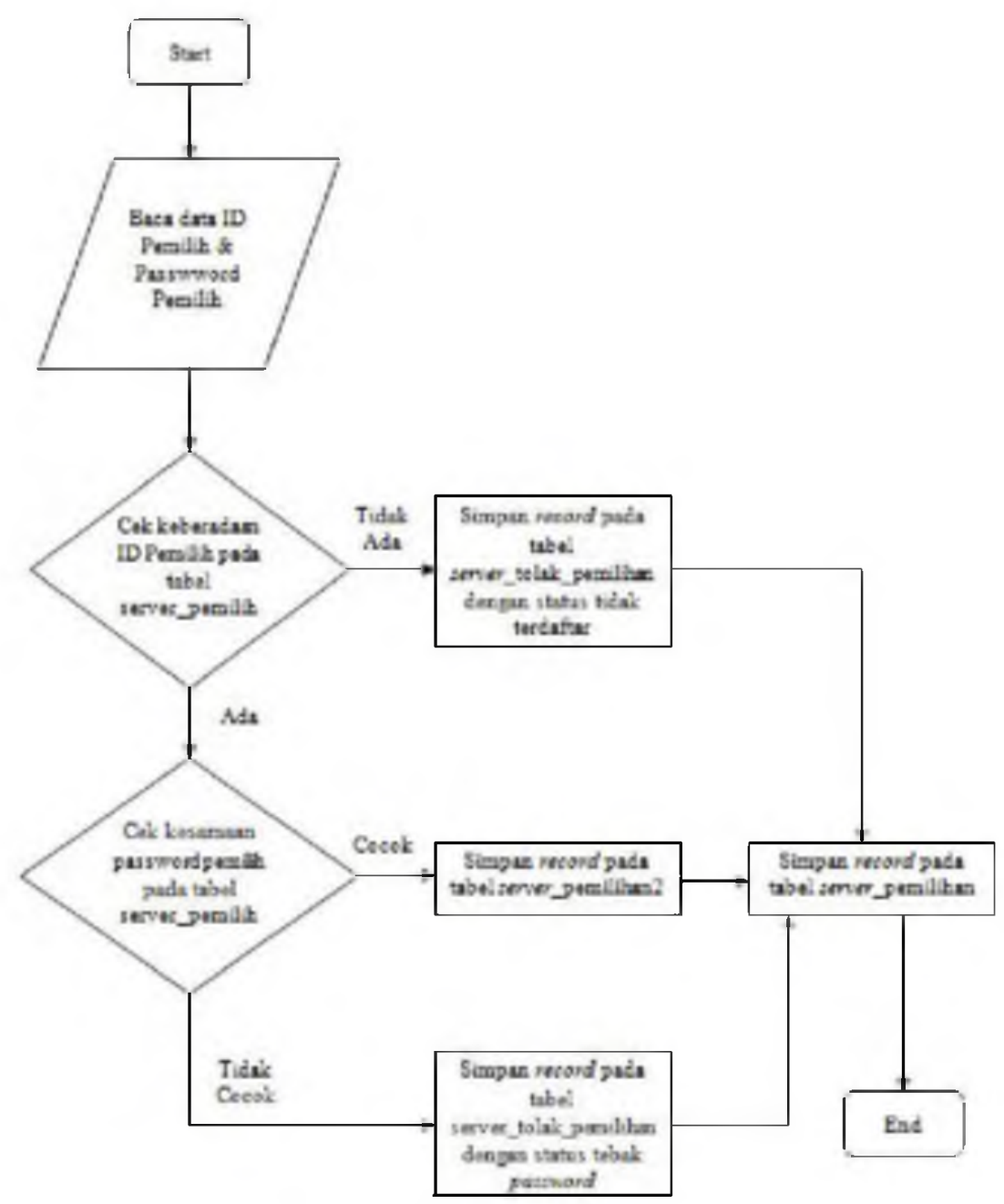

Gambar 2. Diagram alir proses penyaringan pertama 


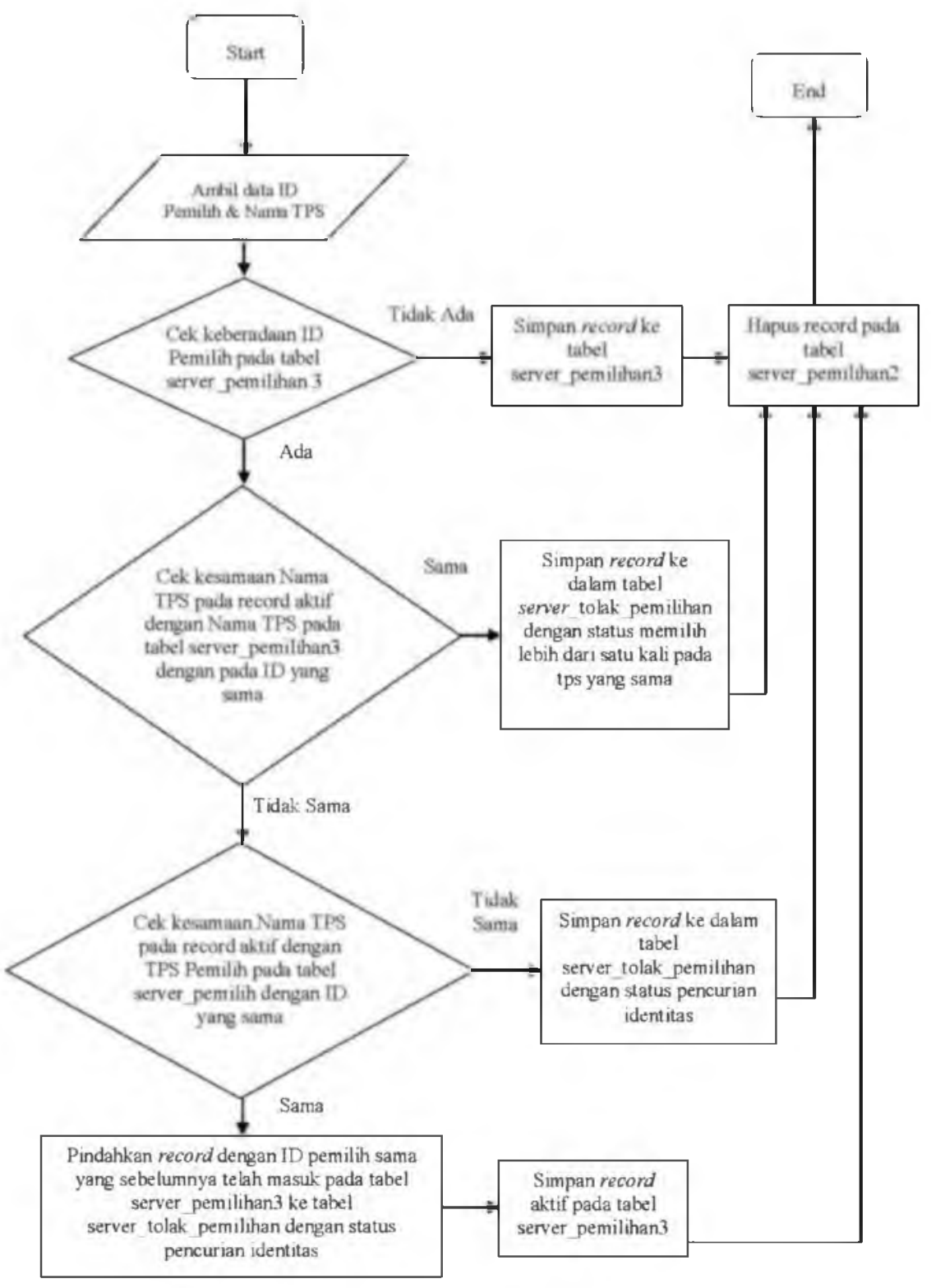

Gambar 3. Diagram alir proses penyaringan kedua

\section{PERANCANGAN SISTEM PEMILIHAN PEMIMPIN MASYARAKAT}

Sistem pemilihan pemimpin masyarakat (SIPPMA) berbasis teknologi informasi terdiri dari 2 aplikasi yang terpisah secara geografis yaitu SIPPMA TPS dan SIPPMA PUSAT serta saling terkoneksi menggunakan jaringan komputer. Aplikasi SIPPMA TPS merupakan aplikasi yang ditempatkan pada TPS yang utamanya bertugas untuk melayani pemilih dalam menyalurkan hak pilihnya. Sedangkan aplikasi SIPPMA PUSAT merupakan aplikasi yang ditempatkan pada pusat perhitungan suara yang bertugas untuk menyaring suara yang di unduh dari SIPPMA TPS dengan menggunakan algoritma Nakula Sadewa dan menghitung hasil suara pemilihan dan laporan pelanggaran yang tersaring algoritma Nakula Sadewa. Skema sederhana penerapan SIPPMA bisa dilihat pada Gambar 5. 


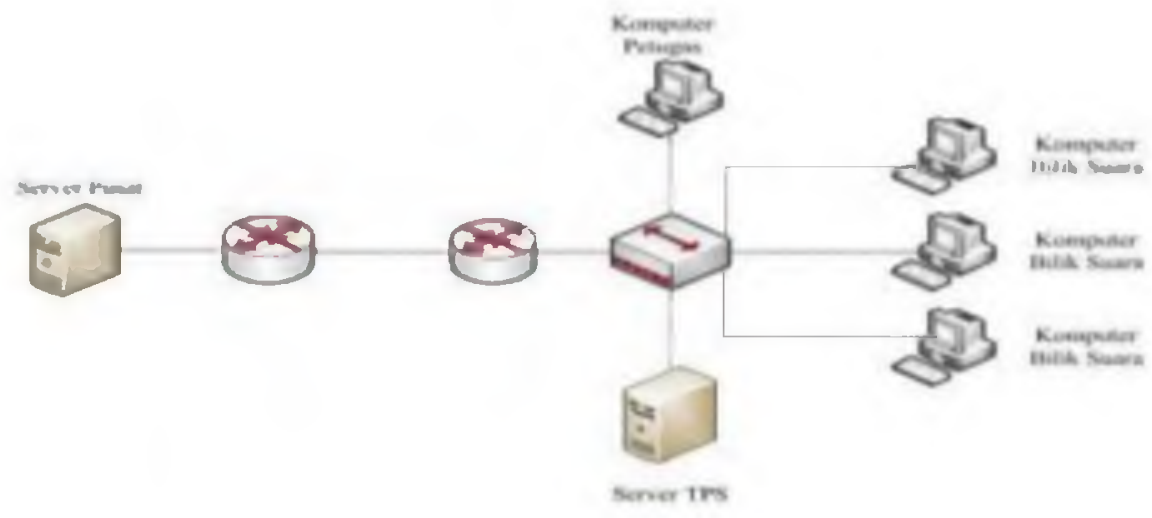

Gambar 5. Skema dasar penerapan SIPPMA

SIPPMA secara keseluruhan mempunyai 4 entitas. Petugas SIPPMA TPS, Admin SIPPMA TPS, Pemilih dan Admin SIPPMA Pusat. Interaksi entitas tersebut kedalam SIPPMA bisa dilihat pada diagram konteks pada Gambar 6.

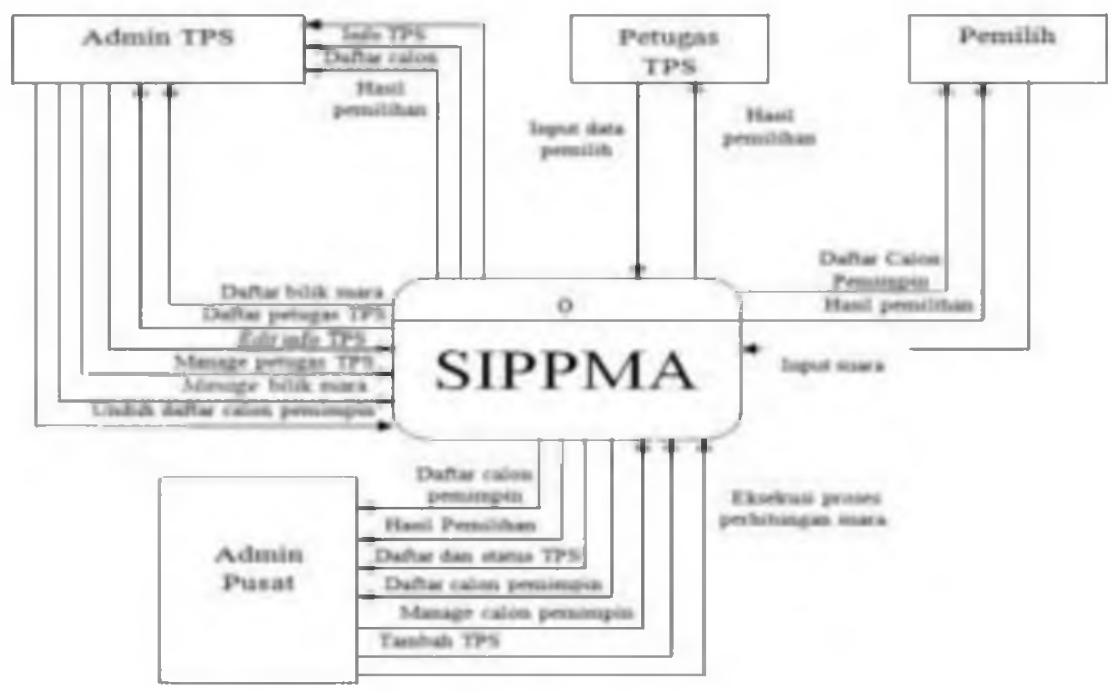

Gambar 6. Diagram Konteks SIPPMA

Berdasarkan diagram konteks diatas, entitas admin pusat bertugas mengoperasikan SIPPMA PUSAT yang digunakan untuk me-manage (tambah dan hapus) daftar calon pemimpin, menambah TPS ke sistem dan mengeksekusi proses filtering pemilihan. Sedangkan feedback dari SIPPMA untuk admin pusat adalah laporan hasil perhitungan suara, rekapitulasi pelanggaran yang terdeteksi oleh proses filtering, daftar calon pemimpin dan juga status koneksi jaringan dan koneksi database milik TPS yang berada dibawah SIPPMA pusat. Entitas admin TPS sendiri bertugas mengoperasikan SIPPMA TPS yang digunakan untuk mengatur bilik suara, mengunduh daftar calon pemimpin dari SIPPMA PUSAT, mengatur (tambah, edit dan hapus) petugas TPS serta berhak mengubah info TPS dimana admin tersebut bertugas. Feedback yang didapat dari SIPPMA TPS adalah info TPS yang bersangkutan, daftar bilik suara, daftar petugas TPS dan juga hasil perhitungan suara serta rekapitulasi pelanggaran. Sedangkan untuk entitas petugas TPS tugasnya hanya satu yaitu menginputkan data pemilih ketika pemilih datang ke TPS. Entitas petugas TPS mendapatkan feedback berupa hasil perhitungan suara dan hasil rekapitulasi pelanggaran. Untuk pemilih, tugasnya hanya satu yaitu memberikan suara pilihan mereka ke dalam SIPPMA. Entitas pemilih mendapatkan 
feedback berupa daftar calon pemimpin ketika akan melakukan pemilihan, hasil perhitungan suara dan hasil rekapitulasi pelanggaran. Gambaran sederhana proses pada SIPPMA bisa dilihat pada DFD Level 0 pada Gambar 7.

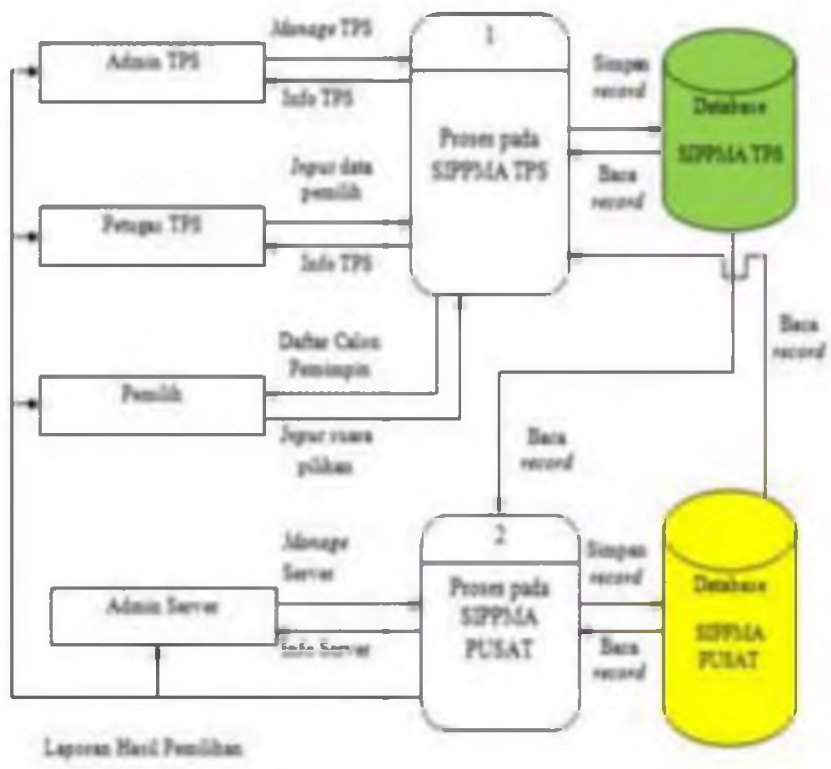

Gambar 7. DFD Level 0 SIPPMA

\section{IMPLEMENTASI DAN ANALISA SISTEM}

\section{Penjelasan Aplikasi}

SIPPMA dibangun dengan menggunakan teknologi web agar bisa dengan mudah terintegrasi dengan sistem yang heterogen dan juga tidak menggunakan banyak resources baik pada hardisk, processor maupun memory.

\section{Uji Fungsi}

Pengujian fungsi SIPPMA akan dilakukan sebanyak 2 kali yaitu uji fungsi di jaringan lokal yang dilaksanakan di Laboratorium Komputasi Sekolah Tinggi Teknologi Adisutjipto (STTA) dan uji fungsi di jaringan internet. Untuk uji fungsi di jaringan lokal, komputer yang akan digunakan berjumlah 13 buah dengan rincian 1 komputer sebagai server SIPPMA PUSAT, 2 komputer sebagai server SIPPMA TPS, 2 komputer sebagai komputer admin masing masing TPS, 2 komputer sebagai komputer petugas masing masing TPS dan 6 komputer sebagai komputer bilik suara. Semua komputer tersebut telah terkoneksi dengan jaringan komputer lokal. Nantinya akan terdapat 2 buah TPS yang masing masing mempunyai 3 komputer buah bilik suara. Berikut adalah detail konfigurasi uji fungsi SIPPMA.

SIPPMA PUSATSTTASIPPMA TPSHALIMSIPPMA TPSWIWEKOBilik Suara 1 TPS HALIMBilik Suara 1 TPS WIWEKOBilik Suara 2 TPS HALIMBilik Suara 3 TPS HALIMBilik Suara 2 TPS WIWEKOBilik Suara 2 TPS WIWEKOKomputer AdminTPS WIWEKOKomputer AdminTPS HALIMKomputer PetugasTPS HALIMKomputer PetugasTPS WIWEKO 


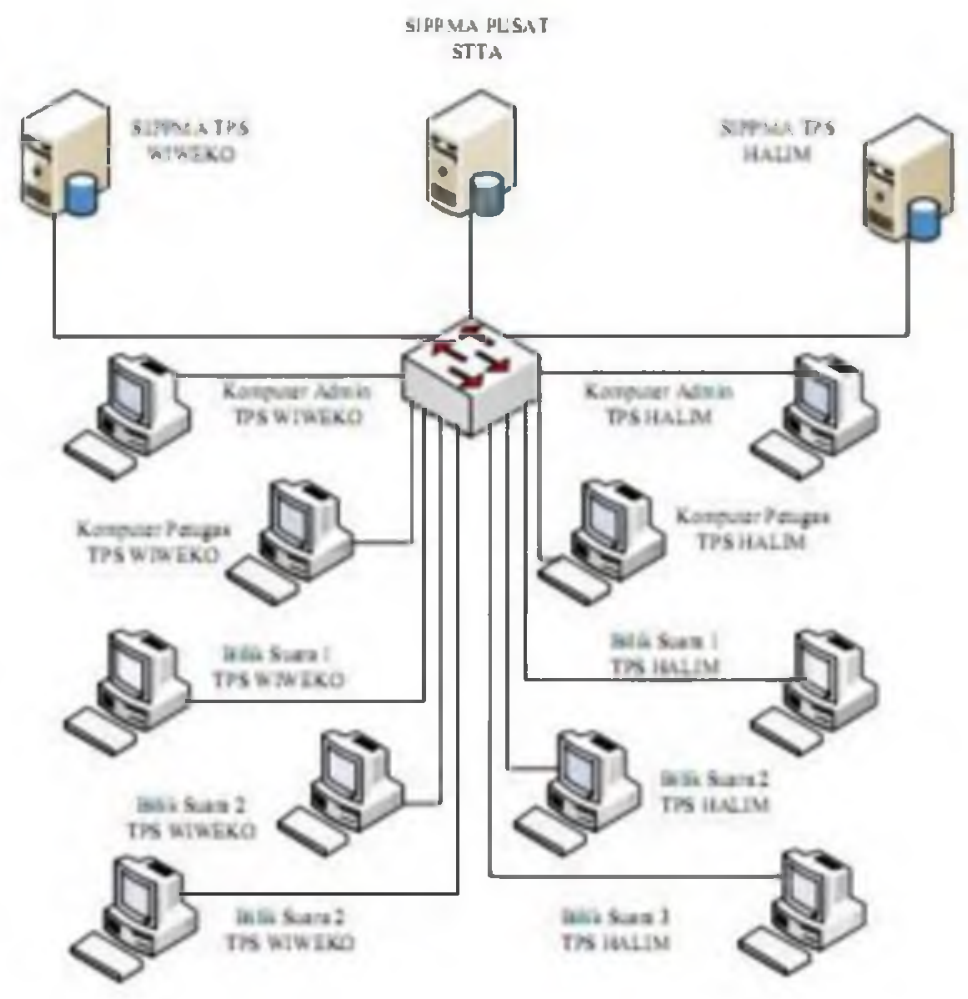

Gambar 8. Skema Pengujian SIPPMA di Lab Komputasi STTA

Sedangkan untuk uji fungsi di jaringan internet, server SIPPMA PUSAT dan server SIPPMA TPS akan terhubung menggunakan internet menggunakan 3 buah static live IP publik dan akan memanfaatkan teknologi VPN untuk mengatasi keterbatasan akses port database Oracle karena komputer server akan berada dibelakang Network Address Translation (NAT) serta mengamakan jalur komunikasi antar server. Sangat tidak disarankan menggunakan IP publik yang dinamis karena akan mengharuskan sistem melakukan proses scanning ulang setiap kali terjadi putus koneksi yang akan membuang waktu cukup banyak. SIPPMA TPS akan menggunakan bandwith sebesar $256 \mathrm{kbps}$, sedangkan untuk SIPPMA PUSAT akan menggunakan bandwith sebesar $768 \mathrm{kbps}$. Konfigurasinya adalah sebagai berikut:

SIPPMA PUSATSLEMAN 1SIPPMA TPSAMBARRUKMOSIPPMA TPSAMBARRUKMO 2103.29.230.2103.29.230.1103.29.230.2Bilik Suara TPS AMBARRUKMOBilik Suara TPS AMBARRUKMO 2Komputer Admin TPS AMBARRUKMO 2Komputer Petugas TPS AMBARRUKMO 2Komputer Petugas TPS AMBARRUKMOKomputer Admin TPS AMBARRUKMO 


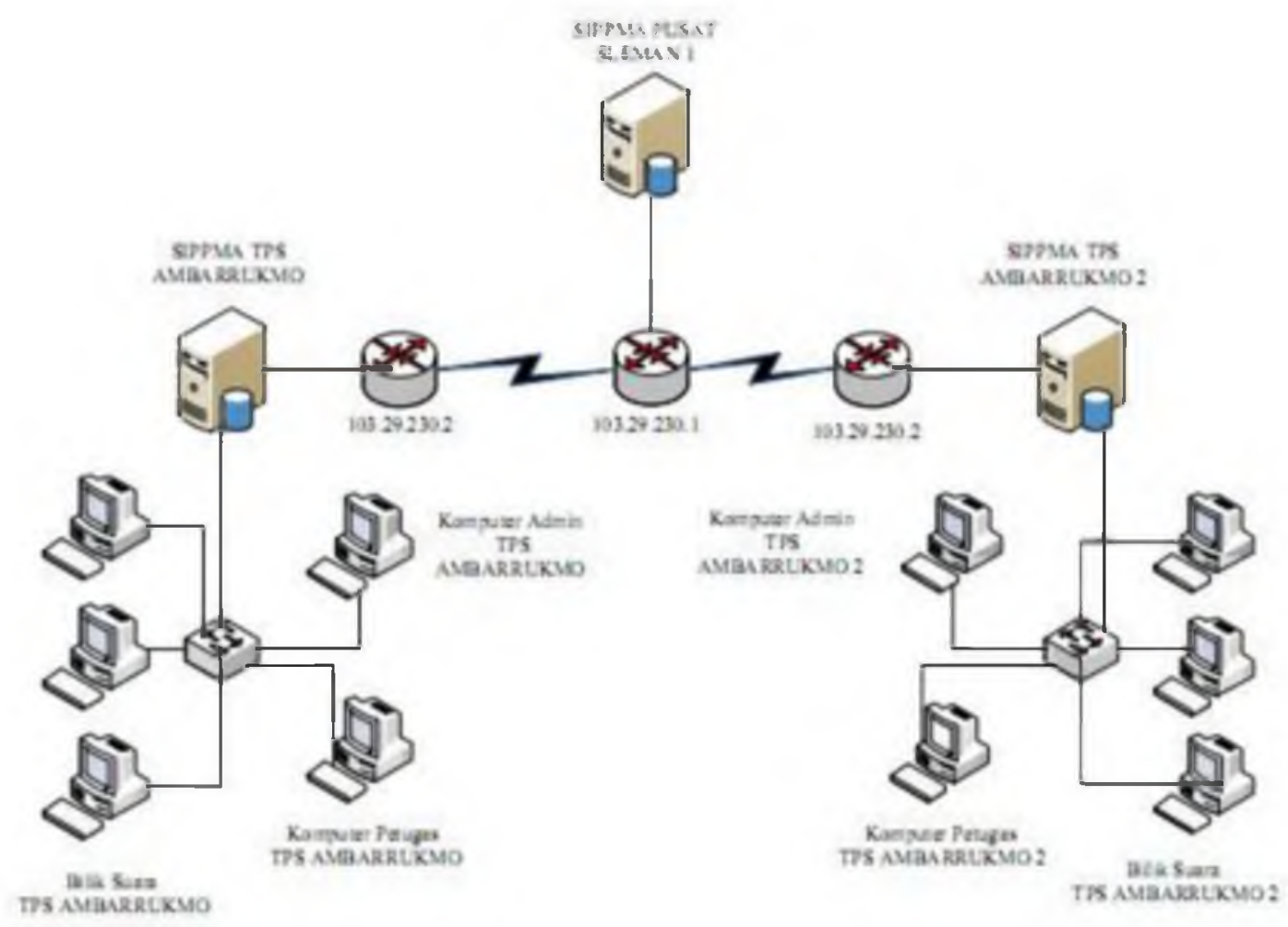

Gambar 9. Skema Pengujian SIPPMA di Jaringan Internet

\section{Analisa Uji Fungsi Pada Jaringan Lokal}

Pengujian SIPPMA pada jaringan lokal akan dilakukan dengan 3 skenario pemilihan, yaitu :

1. Pemilih asli memilih di TPS asal pemilih tersebut. Identitas pemilih yang akan digunakan adalah pemilih dengan nama Nanda yang mempunyai TPS asal TPS Halim dan memilih di TPS Halim.

2. Pemilih asli memilih di TPS di luar TPS asal pemilih tersebut. Identitas pemilih yang akan digunakan adalah pemilih dengan nama Dhaffa yang mempunyai TPS asal TPS Wiweko dan memilih di TPS Halim.

Pemilih palsu memilih diluar TPS asal identitas pemilih yang dicuri. Identitas yang dicuri adalah identitas pemilih dengan nama Nanda yang mempunyai TPS asal TPS Halim dan akan digunakan memilih di TPS Wiweko. Hasil perhitungan pemilihan bisa dilihat pada gambar 10 dimana suara yang valid hanya ada 2 sesuai dengan jumlah pemilih yang sah. 


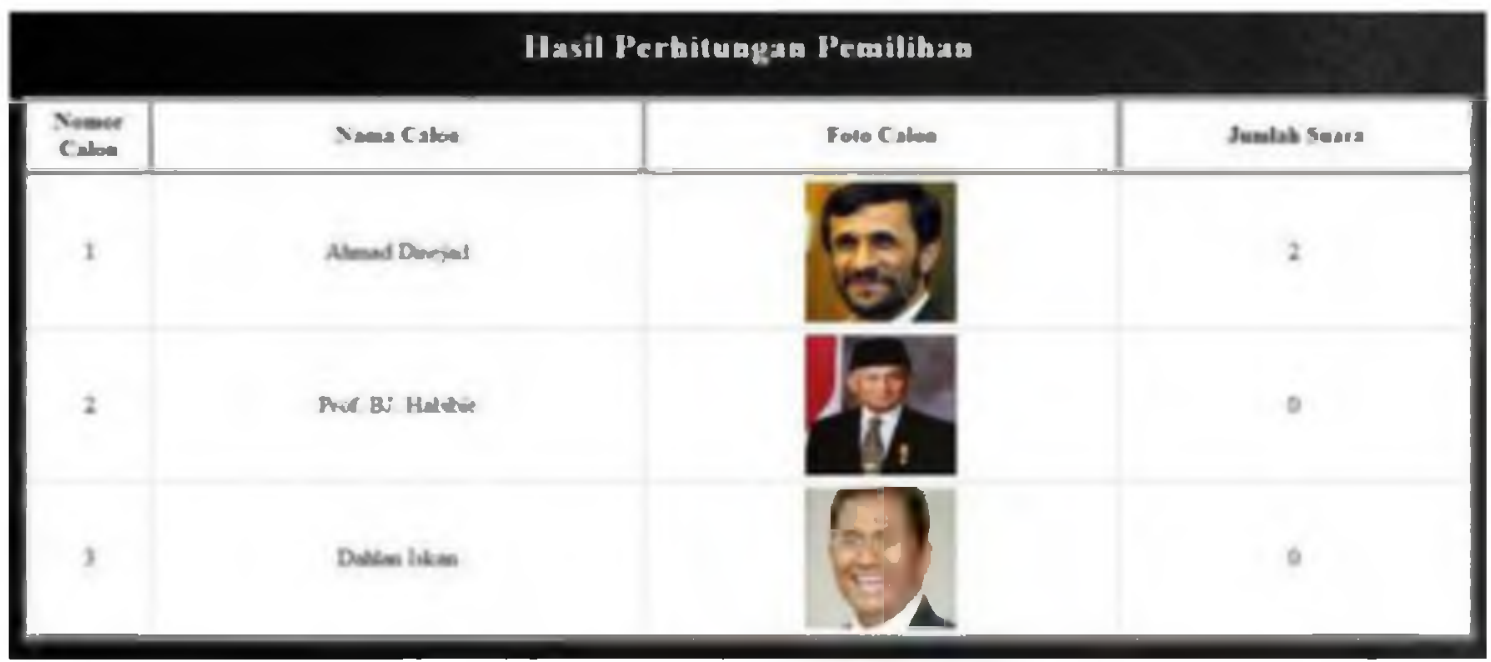

Gambar 10. Hasil Perhitungan Pemilihan Pengujian SIPPMA

\section{Analisa Uji Fungsi Pada Jaringan Internet}

Pengujian uji fungsi pada jaringan internet lebih ditekankan kepada proses pengunduhan data oleh SIPPMA PUSAT dari SIPPMA TPS yang terhubung melalui jaringan internet. Pada pengujian ini akan digunakan 2 buah SIPPMA TPS dengan jumlah total data pemilihan sebanyak 600 data pemilihan, dan berikut adalah status proses unduh data pemilihan yang tersimpan didalam tabel SERVER_DONWLOAD_LOG pada SIPPMA PUSAT.

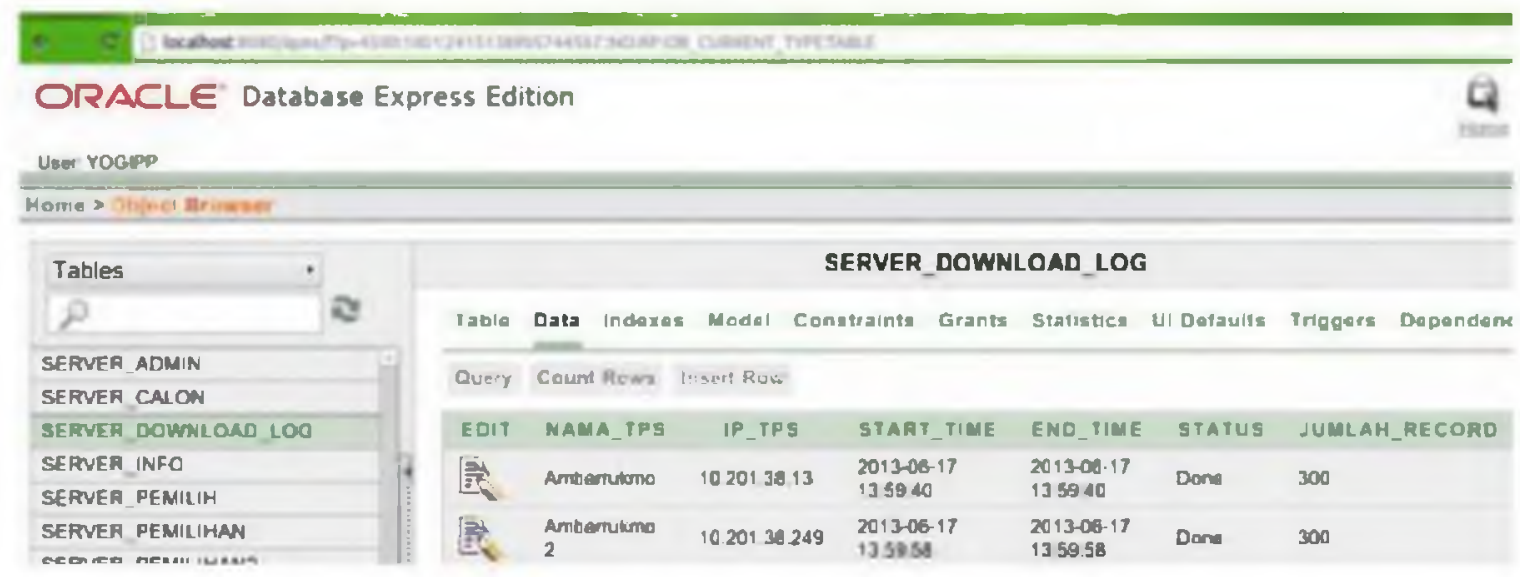

Gambar 11. Isi tabel SERVER_DOWNLOAD_LOG pada SIPPMA PUSAT

Dari nilai yang terdapat pada kolom START_TIME dan END_TIME yang dapat dilihat bahwa proses unduh berjalan dengan sukses dan sangat cepat, serta tidak terdeteksi adanya bottleneck.

\section{KESIMPULAN DAN SARAN}

\section{KESIMPULAN}

Dari penelitian yang telah dilakukan, dapat disimpulkan sebagai berikut :

1. SIPPMA telah terbukti dapat menggantikan proses pemilihan pemimpin masyarakat dari manual menjadi berbasis IT.

2. SIPPMA dapat melakukan proses perhitungan hasil suara lebih cepat dibanding dengan proses manual. 
3. Algoritma Nakula Sadewa pada SIPPMA terbukti dapat digunakan untuk mengatasi kecurangan dalam bentuk penggunaan suara lebih dari satu kali dalam bentuk pencurian identitas pemilih lain pada pemilihan berbasis IT.

\section{SARAN}

1. Hendaknya perangkat lunak ini diberi tambahan fasilitas yang bisa membantu pemilih dengan keterbatasan kemampuan penglihatan.

2. Harus diadakan sosialisasi dan pelatihan sebelum SIPPMA digunakan di lapangan.

3. Disarankan menggunakan layar monitor dengan teknologi touchscreen untuk lebih memudahkan pemilih yang tidak terbiasa dengan teknologi.

4. Pemilih sangat disarankan untuk tetap memilih di TPS asal pemilih.

\section{DAFTAR PUSTAKA}

Clement Salome, Pottle Brian, Singh Puja, 2010, Oracle Database Fundamentals I, Edition 1, Oracle.

Hakim Lukmanul, 2011, Trik Dahsyat Menguasai AJAX Dengan Jquery, Lokomedia.

Hutabarat Bernaridho I, 2004, Pemrogaraman Oracle PL/SQL, Edisi II, ANDI OFFSET.

Jogiyanto, 2005, Analisis \& Desain, Sistem Informasi : Pendekatan Terstruktur Teori Dan Praktik Aplikasi Bisnis, Edisi III, ANDI OFFSET.

Raharjo Budi, 2011, Belajar Otodidak Pemrograman Web Dengan PHP + Oracle, Informatika.

http://www.brighthub.com/internet/web-development/articles/77944.aspx ,

10:32 WIB - 31 July 2013

http:/ / www.w3schools.com/php/func_ftp_get.asp, 10:33 WIB - 31 July 2013

http:/ /php.net/manual/en/function.scandir.php, 10:35 WIB - 31 July 2013

http:/ / www.randomsupport.com/rs/blogs/index.php?title=oracle-10g-express-web-

interface-remote-\&more $=1 \& \mathrm{c}=1 \& \mathrm{tb}=1 \& \mathrm{pb}=1,10: 35$ WIB -31 July 2013

http:/ / stackoverflow.com/questions/7792413/php-checking-if-server-is-alive 10:39 WIB - 31 July 2013

http:/ / www.youtube.com/watch?v=AzWBCNjkT0k, 10:41 WIB - 31 July 2013

http://jembranakab.go.id/index.php?module=e-voting, 10:45 WIB - 31 July 2 
Yogi Priyo Prayogo, Hero Wintolo, Yuliani Indrianingsih 